\title{
Ruokahävikki Suomen kotitalouksissa ja ravitsemispalveluissa
}

Kirsi Silvennoinen ${ }^{1}$, Juha-Matti Katajajuuri ${ }^{1}$, Hanna Hartikainen ${ }^{1}$, Lotta Jalkanen ${ }^{2}$, Heta-Kaisa Koivupuro $^{1}$ and Anu Reinikainen ${ }^{1}$

${ }^{1}$ MTT, Biotekniikka ja elintarviketutkimus, Latokartanonkaari 9, 00790 Helsinki

${ }^{2}$ MTT Taloustutkimus, Latokartanonkaari 9, 00790 Helsinki

etunimi.sukunimi@mtt.fi

\section{Tiivistelmä}

Ruoan päätyminen jätteeksi on ekologisesti ja taloudellisesti kestämätöntä. Raaka-aineiden tuotannosta ja prosessoinnista aiheutuneet ympäristövaikutukset ovat syntyneet turhaan. Yksi yksinkertaisimpia keinoja vähentää elintarvikeketjun ympäristövaikutuksia onkin ehkäistä syntyvää ruokahävikkiä. Selvitimme Foodspill -hankkeessa ruokahävikin määrää ja laatua Suomessa. Koska kansainvälisten tutkimusten mukaan suurimmat ruokahävikkimäärät syntyvät kotitalouksissa ja ravintolapalveluissa, keskitimme mittaukset niihin. Lisäksi hävikkitietoja kerättiin elintarviketeollisuudelta ja kauppaketjuilta.

Syyskuussa 2010 toteutimme seurantatutkimuksen, jossa selvitettiin suomalaisissa kotitalouksissa syntyvän ruokahävikin määrää ja sen laatua. Tutkimukseen osallistui 420 kotitaloutta, joista 380 suoritti tutkimuksen loppuun asti. Ennen tutkimusta osallistujat täyttivät taustatietolomakkeen ja heille lähetettiin keittiövaaka ruokahävikin punnitsemista varten. Tutkimusaika oli kaksi viikkoa ja tulokset kirjattiin päiväkirjaan.

Kotitalouksissa syntyvät ruokahävikkimäärät vaihtelivat tutkimusaikana $0-23,4 \mathrm{~kg} / \mathrm{hlö} \mathrm{ja}$ muutettuna vuositasolle $0-160 \mathrm{~kg} / \mathrm{hlö/vuosi.} \mathrm{Keskimäärin} \mathrm{vuositasolle} \mathrm{muutettuna} \mathrm{ruokahävikkiä}$ syntyi $23 \mathrm{~kg} / \mathrm{hlö.} \mathrm{Suurin} \mathrm{osa} \mathrm{poisheitetystä} \mathrm{ruoasta} \mathrm{oli} \mathrm{nopeasti} \mathrm{pilaantuvaa} \mathrm{tuoreruokaa} \mathrm{ja}$ ruoanlaitosta sekä ruokailusta ylijäänyttä ruokaa. Eniten pois heitettiin vihanneksia $19 \%$, kotiruokaa $18 \%$, maitotuotteita $17 \%$, leipää $13 \%$ sekä hedelmiä ja marjoja $13 \%$. Lihaa, kalaa ja kanamunia heitettiin pois yhteensä $7 \%$ ja valmisruokia $6 \%$.

Kesällä ja syksyllä 2010 ruokahävikin syntymistä mitattiin Helsingin ja Tampereen kaupungin järjestämissä ruokapalveluissa viiden päivän ajan. Mukana tutkimuksessa oli kouluja, päiväkoteja, sairaala ja palvelukeskuksia. Hävikin syntymistä mitattiin myös Helsingin yliopiston opiskelija- ja henkilöstöravintoloissa. Näiden lisäksi järjestettiin pienempiä mittauksia erilaisissa ravitsemispalveluyrityksissä kokonaiskuvan saamiseksi. Mukana oli $\mathrm{mm}$. ala carte ravintoloita, pikaruokaravintoloita, kahviloita ja huoltoasemia. Yhteensä hävikkiä seurattiin 72:ssa ravintolassa. Mittauksissa seurattiin hävikin muodostumista siten että huomioitiin erikseen keittiön valmistushävikki, tarjoiluhävikki ja asiakkaiden jättämät lautastähteet.

Ravitsemispalveluissa ruokahävikin osuudeksi saatiin noin viidennes syötäväksi tarkoitetusta ruoasta. Määrät vaihtelivat ravintolatyypistä riippuen. Keittiöissä, ruuan valmistuksen yhteydessä syntyi suhteellisesti vähiten hävikkiä kun taas eniten hävikkiä syntyi tarjoilutähteistä, etenkin linjastoruokailun yhteydessä. Syy suureen tarjoilutähteen määrään on yleisemmin menekin ennakoinnin vaikeus.

Jos tämän tutkimuksen tulosten perusteella arvioidaan kotitalouksien ja ravitsemispalveluiden ruokahävikkimääriä vuodessa, saadaan yhteensä noin 200 - 250 miljoonaa kiloa turhaan tuotettua ruokaa. Henkilöä kohti laskettuna tämä tekee noin 35 - 45 kiloa vuodessa. Kun mukaan tarkasteluun otetaan myös kaupan ala hävikki, saadaan Suomen ruokahävikkimääräksi yhteensä $260-320$ miljoonaa kiloa.

Asiasanat: ruokahävikki, kotitaloudet, ravitsemispalvelut, päiväkirjatutkimus 


\section{Johdanto}

Elintarviketuotannon ja ruoankulutuksen vaikutuksia ympäristöön ja talouteen on tutkittu paljon viime aikoina niin Suomessa kuin muuallakin maailmassa. Ruoan osuus on yli kolmanneksen suomalaisten kulutuksen ympäristövaikutuksista. Tarkasteltaessa pelkästään ilmastovaikutuksia ravinnon (elintarvikkeet, kauppa, ravintolat, kotitaloudet) osuus kulutuksesta on noin neljäsosa. Vaikutus vesistöihin on rehevöitymisen kautta jopa suurempi. (Seppälä et al 2009, 2011).

Ruoan päätyminen jätteeksi on ekologisesti ja taloudellisesti kestämätöntä. Raaka-aineiden tuotannosta ja prosessoinnista aiheutuneet ympäristövaikutukset ovat syntyneet turhaan. Yksinkertaisimpia keinoja vähentää elintarvikeketjun ympäristövaikutuksia onkin ehkäistä syntyvää ruokahävikkiä. Jotta hävikin määriin päästäisiin vaikuttamaan, ruokahävikin syntyä ja siihen johtaneita syitä on ensin tutkittava riittävän tarkasti. Suomessa ei ole koko ketjun osalta aiempia selvityksiä ja tehdyt tutkimukset ovat rajoittuneet hyvin pieniin otoksiin kotitalouksista (Tarvainen 2009, Koivupuro et al 2011). Euroopassa ruokahävikkiä on tutkittu esim. Iso-Britanniassa ja Ruotsissa (WRAP 2009, KFS 2009). Nämä tutkimukset on tehty jäteanalyyseillä keräämällä tietyn alueen jäteastioiden sisältämät biojätteet ja seulomalla niistä tunnistettavia jätelaatuja. Jäteanalyysimenetelmällä ei ole mahdollista päästä tarkastelemaan ruokahävikin laatua kovin yksityiskohtaisesti eikä siihen johtaneita syitä juuri lainkaan.

Hankkeemme tarkoituksena oli selvittää elintarvikeketjussa syntyvä ruokahävikin määrää ja sen laatua. Lisäksi tutkimuksessa arvioitiin hävikin syitä sekä miten hävikki on jakautunut eri toimijoiden kesken. Tarkastelussa olivat mukana erityisesti kotitaloudet, ravitsemispalvelut ja elintarviketeollisuus. Tässä yhteenvedossa on tarkoituksena esitellä alustavia tuloksia kotitalouksien ja ravitsemispalveluiden osuudesta ruokahävikkiin. Hankkeen loppuraportti julkaistaan huhtikuussa 2012 MTT:n vastuullisuuspäivän yhteydessä.

\section{Aineisto ja menetelmät \\ Kotitaloudet}

Syyskuussa 2010 toteutettiin seurantatutkimus, jossa selvitettiin suomalaisten kotitalouksien ruokahävikkimääriä ja sen laatua. Lisäksi selvitettiin vastaajien sosiodemografiset tiedot ja käyttäytymiseen sekä asenteisiin vaikuttavia taustatietoja. Vastaajat valittiin internet -paneelista ja käytännön järjestelyistä vastasi markkinatutkimusyritys. Tutkimukseen osallistui 420 kotitaloutta, joista 380 (yhteensä 1054 henkilöä), suoritti tutkimuksen hyväksyttävästi loppuun asti (Taulukko 1).

Taulukko 1 Tutkimukseen osallistuneet kotitaloudet ja vastaajat

\begin{tabular}{lc}
\hline & Otoskoko \\
\hline Kotitalouden koko & 58 \\
1 & 135 \\
2 & 79 \\
3 & 76 \\
4 & 32 \\
$\geq 5$ & \\
Vastaajan sukupuoli & 319 \\
Nainen & 61 \\
Mies & \\
Kotitalouden tyyppi & 58 \\
Yksinasuva & 17 \\
Nainen & 122 \\
Mies & 185 \\
Kaksi aikuista & 15 \\
Lapsiperhe & 380 \\
Muu & 174 \\
Kotitaloudet yhteensä & \\
Henkilöitä yhteensä & \\
\hline
\end{tabular}


Taloudet jakautuivat maantieteellisesti neljälle alueelle: pääkaupunkiseudulle $151 \mathrm{kpl}$, Turun alueelle $74 \mathrm{kpl}$, Tampereen alueelle $101 \mathrm{kpl}$ ja Jyväskylän alueelle $54 \mathrm{kpl}$. Ennen tutkimusta osallistujat täyttivät taustatietolomakkeen ja heille lähetettiin keittiövaaka sekä tarkat ohjeet punnitsemista varten.

Kotitaloudet punnitsivat ruokahävikin päivittäin, aina kun poisheitettävää ruokaa syntyi. Tutkimusaika oli kaksi viikkoa ja tulokset kirjattiin päiväkirjaan. Päiväkirjassa oli jokaiselle poisheitolle oma kohtansa, johon merkittiin poisheitetyn ruoan painon ja laadun lisäksi syy, kuten "pilaantunut", "päiväysvanhentunut" jne. Merkitseminen oli tehty vastaajalle helpoksi antamalla laadulle valmiit otsikot kuten "leipä" , "peruna ja perunavalmisteet" , "kotona tehty ruoka" tai "valmisruoka". Näin vastaajan tarvitsi vain rastittaa oikea kohta lomakkeessa. Tämän lisäksi taloudet keräsivät kolmen viikon ajan ostoskuittinsa kotiin hankitun ruokamäärän arvioimista varten.

Tässä tutkimuksessa arvioitiin vain vältettävissä olevaa ruokahävikkiä eli kaikkea sitä poisheitettyä ruokaa ja raaka-ainetta, joka olisi voitu jossain vaiheessa toisin säilyttäen tai valmistaen syödä. Muuta biojätettä kuten kahvin poroja tai luita ei tutkimuksessa mitattu. Nestemäisistä elintarvikkeista mukana oli vain maito, koska kaikkien nesteiden mittaus arvioitiin osallistujille liian hankalaksi.

\section{Ravitsemispalvelut}

Tutkimukseen osallistui yhteistyöyrityksinä kaksi kunnallista ravitsemispalveluiden tuottajaa (Tampereen Ateria ja Palmia) ja Helsingin yliopistojen ravintoloista vastaava yrittäjä (UniCafe). Kyseisistä yrityksistä tutkimukseen osallistui yhteensä 56 toimipistettä. Mukana oli peruskouluja, lukioita, päiväkoteja, ammattioppilaitoksia, sairaaloita, työpaikkaravintoloita ja vanhusten palvelukeskuksia. Näissä ravintoloissa tutkimusaika kesti viisi päivää, maanantaista perjantaihin.

Muu ravintola-ala kuten ruokaravintolat, kahvilat, huoltoasemat ja vastaavat ruoka-annoksia myyvät toimipisteet osallistuivat lyhyemmällä, päivän mittaisella tutkimusjaksolla. Näitä ravintoloita oli tutkimuksessa mukana yhteensä $17 \mathrm{kpl}$. Osallistuneita ravintoloita tai yritysten toimipisteitä oli siten yhteensä $72 \mathrm{kpl} \mathrm{ja} \mathrm{tutkimuspäiviä} \mathrm{oli} \mathrm{yhteensä} 292 \mathrm{kpl}$.

Ruokahävikki mitattiin tutkimusaikana ravintoloissa siten, että saatiin selville valmistuksessa ja tarjoilussa hävikiksi joutuneen ruoan määrä sekä asiakkaiden lautastähteiden määrä. Lisäksi selvitettiin valmistetun ja tarjotun ruoan määrä syntyneen hävikin suhteuttamista varten.

Tutkimusajanjakso oli kunnallisissa ruokapalveluissa yleisimmin lounas, mutta vanhustenpalvelukodeissa ja sairaalassa myös illallinen. Anniskeluravintoloissa ja kahviloissa mittausaika kesti yhden työpäivän, ravintolan avautumisesta sulkemisajankohtaan. Ruokahävikin ja biojätteen mittaus tapahtui ravintolassa päivän päätteeksi henkilökunnan tai tutkijoiden punnitessa jaotellut jätteet. Lisäksi he täyttivät lomakkeet, joihin merkittiin päivittäin valmistettu ruokamäärä, keittiössä syntynyt hävikki, tarjoilun hävikki ja lautastähteiden määrä. Lautastähteiden koostumusta tarkasteltiin lisäksi tutkijoiden toimesta 33 päivänä eri toimipisteissä.

\section{Tulokset}

\section{Kotitaloudet}

Kotitalouksissa syntyvät ruokahävikkimäärät vaihtelivat tutkimusaikana $0-23,4 \mathrm{~kg} / \mathrm{hlö} \mathrm{ja} \mathrm{muutettuna}$ vuositasolle $0-160 \mathrm{~kg} / \mathrm{hlö/vuosi}$. Keskimäärin vuositasolle muutettuna ruokahävikkiä syntyi 23 $\mathrm{kg} / \mathrm{hlö.} \mathrm{Suurin} \mathrm{osa} \mathrm{poisheitetystä} \mathrm{ruoasta} \mathrm{oli} \mathrm{nopeasti} \mathrm{pilaantuvaa} \mathrm{tuoretavaraa} \mathrm{ja} \mathrm{ruoanlaitosta} \mathrm{sekä}$ ruokailusta ylijäänyttä ruokaa.

Ruokahävikki muodostui kaikenlaisesta ruoasta: eniten pois heitettiin vihanneksia (19\%), kotiruokaa (18\%), maitotuotteita (17\%) leipää (13\%) sekä hedelmiä ja marjoja (13\%). Lihaa, kalaa ja kanamunia heitettiin pois $7 \%$ ja valmisruokia $6 \%$. Kotiruoka sisälsi kotona valmistettuja erilaisia ruokalajeja kuten laatikoita, patoja, kastikkeita, puuroa ja keittoja. Valmisruoka sisälsi laatikoiden ja muiden aterioiden lisäksi mm. hampurilaisia, pizzaa ja vauvanruokia kuten korvikemaitoa. Säilykkeitä ja muita pitkän käyttöajan tuotteita kuten esim. napostelutuotteita heitettiin pois suhteellisen vähän, vain $2,5 \%$. (Kuva 1 ).

Poisheiton suurimmat syyt olivat, että ruoka oli jollain tavoin pilaantunut esim. homehtunut (29\%), päiväys vanhentunut (19\%), jäi lautastähteeksi (14\%), ruokaa valmistettiin liikaa (13\%), ei 
haluttu syödä enää (10\%), ruoka ei näytä pilaantuneelta mutta ei haluta ottaa riskiä (9\%) ja muista syistä $(7 \%)$.

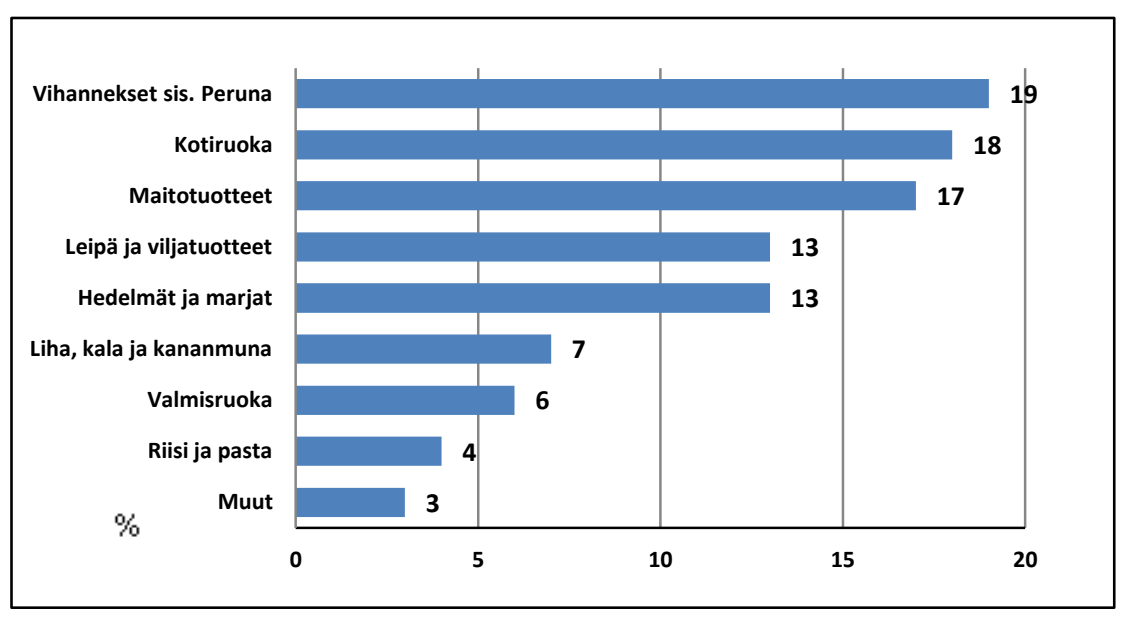

Kuva 1. Eri ruoka-aineiden osuus poisheitetystä ruoasta kotitalouksissa

\section{Ravitsemispalvelut}

Ruokahävikkiä syntyi vaihtelevasti suhteessa valmistettuun ruokamäärään riippuen ravintolatyypistä: suhteellisesti eniten hävikkiä syntyi päiväkodeissa, vanhustenpalvelutaloissa ja sairaaloissa. Vähiten hävikkiä syntyi pikaruokaruokapaikoissa. Näiden väliin jäivät henkilöstöravintolat, koulut, kahvilat ja annosravintolat.

Ruokahävikin syntymiseen vaikutti ruuan tarjontatapa. Tutkimuksessa havaittiin selkeä ero ns. ala carte -ravintoloiden, joissa annokset valmistetaan tilauksesta, ja buffet-tyyppisten ravintoloiden, joissa asiakas ottaa ruuan itse linjastosta, kesken. Mikäli ruoka otetaan itse linjastosta, oli suurin ruokahävikin syy tarjoiluhävikki. Tähän on syynä ennen kaikkea menekin ennustamisen vaikeus mutta myös mm. lainsäädäntö, joka asettaa tiukat rajat lämpöhauteissa olleiden ruokien uudelleen hyödyntämiselle. Suurin osa koko ravitsemispalvelusektorin tuottamista annoksista tarjotaan siten, että ruokailija saa itse ottaa haluamansa määrän ruokaa (mm. henkilöstöravintolat, koulut).

Kunnallisia ravintoloita tarkasteltaessa ruokahävikkiä eniten aiheutti tarjoiluhävikki. Sen sijaan ravintoloissa, joissa ruoka valmistetaan tilauksesta, eniten ruokahävikkiä aiheutui ruokailijoiden lautastähteistä. Syntyvän lautastähteen määrä vaihteli kuitenkin suuresti ravintoloittain riippuen mm. ravintolan tyypistä ja toimintavasta, joka puolestaan määritti tarjottavat annoskoot ja ruokalistan.

\section{Tulosten tarkastelu ja johtopäätökset}

\section{Kotitaloudet}

Suomessa ostetaan ruokaa keskimäärin $500-600 \mathrm{~kg}$ vuodessa henkilöä kohti ja verrattaessa hävikkimääriä (n. $23 \mathrm{~kg} / \mathrm{hlö)}$ ostettuihin ruokamääriin muodostuu hävikki noin viideksi prosentiksi (Tike 2010). Yhteensä Suomen kotitalouksissa ruokaa heitetään silloin pois noin 120 - 160 miljoonaa kiloa. Tämä on noin kaksinkertainen määrä esim. verrattuna kauppojen poisheittämiin ruokamääriin (Stenmark et al 2011).

Eniten poisheitettävät ruoat kuten vihannekset ja kotiruoka eroavat toisistaan poisheittosyiden osalta. Vihannekset heitettiin roskiin niiden pilaantuessa kun taas kotiruokaa heitettiin pois kun ruokaa valmistettiin liikaa tai sitä jäi lautastähteiksi. Maitotuotteiden osalta syynä olivat parasta ennen tai viimeisen päiväyksen umpeutuminen. Leipä oli useimmiten pilaantunut tai sitä ei haluttu syödä enää, jolloin se on luultavasti ollut kuivahtanut ja siten vähemmän houkutteleva.

Kysyttäessä suosituimpia keinoja vähentää hävikkiä vastaajat valitsivat mm. seuraavia:

- Uuden paketin avaaminen vasta kun vanha on loppunut

- Säilyttämällä elintarvikkeet oikein

- Annostelemalla lautaselle se määrä ruokaa joka varmasti syödään 
- Syömällä helpoimmin pilaantuvat tuotteet ensin

On huomattava että päiväkirjamerkinnöistä laskettu keskimääräinen hävikki jää kansainvälisiin tutkimuksiin verrattuna matalammaksi. Muualla tehdyt tutkimukset eivät kuitenkaan ole vertailukelpoisia menetelmiensä erilaisuuden vuoksi. Koska kotitaloudet punnitsivat ja kirjasivat hävikin itse, on mahdollista että vastaajat eivät tehneet kaikkea tarkasti ja todenmukaisesti. Koejärjestelyn punnitustilanne saattaa vaikuttaa itsessäänkin hävikkiä pienentävästi. Toisaalta viimeaikainen pääkaupunkiseudulla tehty laaja biojäteanalyysi osoittaa saman suurusluokan ruokahävikkimäärää alueen kotitalouksissa (HSY 2011). On myös mahdollista että osalla tutkimukseen osallistuneista talouksista hävikkiä syntyy jo normaalistikin kaikkiin kotitalouksiin verrattuna vähän. Vastanneista kotitalouksista oli suurempi osuus lapsiperheitä ja useita henkilöitä sisältäviä talouksia (2,8 henkilöä) kuin Suomessa keskimäärin (2,07 henkilöä) (SVT 2010).

Toisaalta päiväkirja-aineisto mahdollistaa tulosten selittävien tekijöiden selvittämisen kotitalouksista (Koivupuro et al. 2011).

\section{Ravitsemispalvelut}

Kunnalliset ravitsemispalvelut ovat olennainen osa suomalaista ruokakulttuuria koska jopa puolet kodin ulkopuolella syötävistä aterioista nautitaan kunnallisissa ravitsemispalveluissa (The Nielsen company 2008). Väestöstä kolmasosa käyttää julkisia ravitsemispalveluita päivittäin ja kouluissa tarjotaan ilmainen lounas. Kouluruokailu on tärkeä paitsi ravitsemuksellisesti myös kasvatuksellisesti, lapset ja nuoret oppivat syömään monipuolisesti kaikenlaisia ruokia. Tämä voi lisätä ruokahävikin määrää mutta tarjoaa myös tilaisuuden uusien toimintatapojen opettelulle. Oppilaat osallistuvat lisäksi kotitaloustunneille, joten opetukseen kuuluu ruoka-aineiden kestävä käyttö ja myös hävikin välttäminen.

Ruokahävikkiä syntyi eri määriä ravintolatyypistä ja ruokapalvelun työvaiheesta riippuen. Ruoan valmistuksen yhteydessä keittiöissä hävikkiä syntyi melko vähän, samoin asiakkaiden lautastähteistä, varsinkin kunnallisissa ja henkilöstöruokailua järjestävissä ravintoloissa. Anniskeluravintoloissa ja pikaruokapaikoissa ruoanvalmistuksen ja lautastähteiden osuudet olivat suuremmat. Yleensä ottaen suurimmat hävikkimäärät olivat tarjoilusta ylijääneet ruoat, joita ei voitu enää säilyttää eikä tarjota uudelleen, tosin anniskeluravintoloissa, pikaruokapaikoissa ja sairaaloissa lautastähteitä syntyi enemmän. Tämä selittyy ruoan tilaamisella ruokalistalta linjaston sijaan ja sairaaloissa annoskokojen ja ruoankulutuksen vaikealla arvioimisella.

Hävikkiä voidaan hallita järjestelmällisellä toiminnan johtamisella ja hävikkitietojen dokumentoinnilla. Säännöllisellä mittaamisella voidaan hävikin määrissä tapahtuvia muutoksia seurata ja löytää eniten tarkkailua vaativat kohdat ravintolassa. Pelkkä hävikkimäärien arviointi näyttäisi kertovan huonosti todellisista määristä, kunnallisten ruokapalveluista vastaavien henkilöiden arviot biojätteen määristä olivat kysyttäessä hyvinkin alhaiset, yleensä vain 0-5 \% (Risku-Norja et al 2010).

\section{Yhteenveto kotitalouksien ja ravitsemispalveluiden ruokahävikistä}

Jos tämän tutkimuksen tulosten perusteella arvioidaan kotitalouksien ja ravitsemispalveluiden ruokahävikkimääriä vuodessa, saadaan yhteensä noin 200 - 250 miljoonaa kiloa turhaan tuotettua ruokaa. Henkilöä kohti laskettuna tämä tekee noin 35 - 45 kiloa vuodessa. Kun mukaan tarkasteluun otetaan myös kaupan ala, saadaan Suomen ruokahävikkimääräksi yhteensä 260 - 320 miljoonaa kiloa. (Taulukko 2).

Taulukko 2. Ruokahävikki yhteensä ja henkilöä kohti vuodessa

\begin{tabular}{lcccc}
\hline Toimiala & Kotitaloudet & Ravitsemispalvelut & Kauppa & Yhteensä \\
\hline Yhteensä milj kg vuodessa & $120-160$ & $75-85$ & $65-75$ & $260-320$ \\
\hline Toimiala & Kotitaloudet & Ravitsemispalvelut & Kauppa & Yhteensä \\
\hline Henkilöä kohti kg vuodessa & $20-30$ & $14-16$ & $12-14$ & $46-60$
\end{tabular}




\section{Kirjallisuus}

HSY 2011. Pääkaupunkiseudun biojätteen koostumus. Helsinginseudun ympäristöpalvelut. http://www.hsy.fi/tietoahsy/Documents/Julkaisut/6_2011_Paakaupunkiseudun_biojatteen_koostumus.pdf

KFS 2009 Konsument Föreningen Stockholm, 2009, Rapport från en slaskhink.

Koivupuro, H.-K., Jalkanen, L., Katajajuuri, J.-M., Reinikainen, A. \& Silvennoinen, K. 2010. Food waste in the supply chain. Elintarvikeketjussa syntyvä ruokahävikki, kirjallisuuskatsaus. MET report 12: 73 p. http://www.mtt.fi/mttraportti/pdf/mttraportti12.pdf

Koivupuro, H., Hartikainen, H., Katajajuuri, J.-M., Silvennoinen, K., Heikintalo, N. Reinikainen, A., \& Jalkanen , L. 2011. Influence of socio-demographical, behavioural and attitudinal factors on the amount of avoidable food waste generated in Finnish households (accepted, International Journal of Consumer Studies ).

OSF Official Statistics of Finland. 2010: Dwellings and housing conditions. Appendix table 1. Householddwelling units by number of persons 1960-2010. Helsinki: Statistics Finland. [WWW document]. URL http://www.stat.fi/til/asas/2010/asas_2010_2011-05-24_tau_001_en.html.

Risku-Norja, H., Kurppa, S., Silvennoinen, K., Nuoranne A. \& Skinnari, J. 2010:Julkiset ruokapalvelut ja ruokakasvatus: arjen käytäntöjen kautta kestävään ruokahuoltoon. MTT kasvu 10.

Seppälä, J., Mäenpää, I., Koskela, S., Mattila, T., Nissinen, A., Katajajuuri, J.-M., Härmä, T., Korhonen, M.-R., Saarinen, M. \& Virtanen, Y. 2009 Environmental impacts of material flows caused by the Finnish economy. Suomen ympäristö 20/2009, 134 s. (SYKE).

Seppälä, J., Mäenpää, I., Koskela, S., Mattila, T., Nissinen, A., Katajajuuri, J.-M., Härmä, T., Korhonen, M.-R., Saarinen, M. \& Virtanen, Y. 2011. An assessment of greenhouse gas emissions and material flows caused by the Finnish economy using the ENVIMAT model. Journal of Cleaner Production 19 (16): 1833-1841 (November 2011).

SVT Suomen virallinen tilasto: Asunnot ja asuinolot [verkkojulkaisu]. Liitetaulukko 1. Asuntokunnat koon mukaan ja asuntokuntien keskikoko 1960-2010. Helsinki: Tilastokeskus [viitattu: 29.11.2011]. Saantitapa: http://www.stat.fi/til/asas/2010/asas_2010_2011-05-24_tau_001_fi.html.

Stenmark, Å., Hanssen, O., Silvennoinen, K., Katajajuuri, J-M. \& Werge, M. 2011. Initiatives on Prevention of Food Waste in the Retail and Wholesale Trades. Report. Swedish Environmental Research Institute. Juni 2011.

Tarvainen, M. 2009. Rokka rikassa - Pääkaupunkiseudun lapsiperheiden ruokajätteet. YTV:n julkaisuja 25/2009. Helsinki 2009.

Tike 2010. Balance Sheet for Food Commodities 2008 and 2009 (preliminary).

http://www.maataloustilastot.fi/sites/default/files/ravintotase_2009_ennakko.pdf

The Nielsen Company 2008. Horeca rekisteri 2008.

WRAP 2009. Household Food and Drink waste in the UK. Final report. 94 p. 